\title{
Anti-IGF-1R monoclonal antibody inhibits the carcinogenicity activity of acquired trastuzumab- resistant SKOV3
}

Wei Wang ${ }^{1,2+}{ }^{2}$, Yan Zhang ${ }^{3+}$, Ming Lv ${ }^{2}$, Jiannan Feng ${ }^{1,2}$, Hui Peng ${ }^{4}$, Jing Geng ${ }^{2}$, Zhou Lin², Tingting Zhou ${ }^{2}$, Xinying $\mathrm{Li}^{2}$, Beifen Shen ${ }^{2}$, Yuanfang $\mathrm{Ma}^{1 *}$ and Chunxia Qiao ${ }^{2^{*}}$

\begin{abstract}
Background: Antibody resistance, not only de novo but also acquired cases, usually exists and is related with lower survival rate and high risk of recurrence. Reversing the resistance often results in better clinical therapeutic effect. Previously, we established a trastuzumab-resistant ovarian cancer cell line, named as SKOV3-T, with lower HER2 and induced higher IGF-1R expression level to keep cell survival.

Methods: IGF-1R was identified important for SKOV3-T growth. Then, a novel anti-IGF-1R monoclonal antibody, named as LMAb1, was used to inhibit SKOV3-T in cell growth/proliferation, migration, clone formation and in vivo carcinogenicity.

Results: In both in vitro and in vivo assays, LMAb1 showed effective anti-tumor function, especially when being used in combination with trastuzumab, which was beneficial to longer survival time of mice as well as smaller tumor. It was also confirmed preliminarily that the mechanism of antibody might be to inhibit the activation of IGF-1R and downstream MAPK, AKT pathway transduction.

Conclusion: We achieved satisfactory anti-tumor activity using trastuzumab plus LMAb1 in trastuzumab-resistant ovarian cancer model. In similar cases, not only acquired but also de novo, good curative effect might be achieved using combined antibody therapy strategies.
\end{abstract}

Keywords: IGF-1R, Monoclonal antibody, Acquired resistant, Trastuzumab, Ovarian cancer

\section{Introduction}

An antibody $(\mathrm{Ab})$, also known as an immunoglobulin (Ig), is a large Y-shape protein produced by plasma cells that is used by the immune system to identify and neutralize foreign object, such as bacteria and virus, which is called "antigen". Monoclonal antibody $(\mathrm{mAb})$ recognizes a unique part of the antigen specifically, e.g. tumor associated antigens like EGFR or HER-2, and these mAbs have been widely used as standard treatment in clinical trails.

Along with more knowledge of the structure and potential modifications of mAbs plays an increasingly important

\footnotetext{
*Correspondence: mayf@henu.edu.cn; bioqcx1982@hotmail.com

${ }^{\dagger}$ Equal contributors

'Laboratory of Cellular and Molecular Immunology, Institute of Immunology, Henan University, Kaifeng 475001, China

${ }^{2}$ Laboratory of Immunology, Institute of Basic Medical Sciences, PO Box 130(3),

Taiping Road \#27, Beijing 100850, China

Full list of author information is available at the end of the article
}

role in cancer immunotherapy. Over the past few years many biological technologies have been invented to prepare therapeutic antibody drugs, including chimeric, humarized or fully human antibodies, radioimmunotherapeutic agents, antibody-drug conjugates (ADCs), and bispecific T cell engagers (BiTEs), etc. As early as 1998, the FDA approved the use of Trastuzumab, the first antiHER2 humanized antibody, for HER2-positive breast cancer. In 2012, the FDA approved another anti-HER2 drug, Pertuzumab, for advanced or metastatic breast cancer with high or low expression level of HER2. There has also been a lot of excitement about the development of antibodydrug conjugates, as these drugs are designed to improve local delivery of highly toxic chemotherapeutics meanwhile simultaneously attempting to minimize systemic toxicity. 
In 2013, an anti-HER2 ADC drug, trastuzumab emtansine, was approved by the FDA for patients with metastatic HER2-positive breast cancer [1].

HER2, a receptor tyrosine-protein kinase also known as erbB-2/CD340, belongs to the transmembrane epidermal growth factor type II receptor family. It represents the prototype of a stable molecular abnormality endowed with well-characterized functional consequences. It has been found in several of the most common solid tumors, including but not limited to ovarian, breast, colon, nonsmall cell lung cancer, endometrial, prostate and cervical cancer [2-5]. More importantly, HER2 overexpression has been shown to correlate with a worse prognosis in both node-positive and node-negative breast cancer patients. It also has potential therapeutic and diagnostic value in other types of solid tumor, e.g. multiple gynecologic cancers [6].

Trastuzumab (Herceptin ${ }^{\circ}$, Genentech, CA, USA) is a humanized monoclonal IgG1 antibody that works both through initiation of ADCC and recruitment of NK cells as well as restrain of downstream effectors [7-9]. It was FDA-approved in 1998 as an adjunct to cyclophosphamide, paclitaxel and/or doxorubicin in the treatment of early-stage HER2 positive breast cancer, and as a single drug for adjuvant treatment of early-stage, HER2 positive, high-risk ER/PR-negative breast cancers following multi-modality anthracycline-based therapy [10]. Trastuzumab has provided a promising therapeutic advantage in not only breast cancer but in other tumor types; moreover, combination therapy with trastuzumab and chemotherapeutics is generally more effective than single agents in HER2 positive breast and gastric cancer.

Pertuzumab (Omnitarg, Genentech, South San Francisco, CA, USA) is a humanized IgG1 mAb. It is a HER heterodimerization inhibitor that binds domain II of the extracellular HER2. Pertuzumab received the US FDA approval for the treatment of HER2-positive metastatic breast cancer on June 8, 2012. Compared to trastuzumab, pertuzumab inhibits a broader array of downstream signal transduction pathways through inhibition of lateral signal transduction [11-15].

Trastuzumab emtansine (Kydcyla/T-DM1, Genentech/ Roche) is a novel antibody-drug conjugate approved in 2013 with trastuzumab for targeted delivery and antimicrotubule agent DM1 for cytotoxicity. In contrast to trastuzumab, T-DM1 not only inhibits the growth of cancer cells by binding to the HER2 receptor, but also kills them by emtansine, for emtansine can enter cells and bind to tubulin [16]. T-DM1 has demonstrated robust clinical activity in pretreated HER2-positive breast cancer patients with a $43.6 \%$ objective response rate and median PFS of 9.6 months [17]. The global marketing of TDM1 may over 3 billion in 2018 predicted by Bloomberg Limited Partnership recently.
Although antibody drugs against cancers have made great clinical achievements, there still exist many cases in which the patients do not respond to the antibody at the very beginning; besides, many patients who received antibody treatment relapsed because of subsequent antibody resistance. For instance, many HER2-positive breast cancers do not respond to trastuzumab treatment (de novo resistance), while many trastuzumab-responsive patients develop resistance after continuous trastuzumab infusion within one year (acquired resistance) [18,19]; meanwhile, although the treatments have improved, the major problem in the hematological multiple myeloma (MM) is the resistance to therapy. Most patients will eventually relapse or become resistance to bivatuzumab, which is a humanized anti-CD44v6 variant monoclonal antibody to inhibit cell adhesion to hyaluronan [20,21]; besides, two anti-epidermal growth factor receptor (EGFR) mAbs, the chimeric IgG1 mAb cetuximab and the human IgG2 mAb panitumumab, have shown relevant clinical effect in chemotherapy-refractory metastatic colorectal cancer (mCRC) [22-25]. Because of common resistance to anti-EGFR mAbs, recent guideline recommendations suggest that anti-EGFR mAbs be given only to patients with KRAS wild-type mCRC [26,27]. However, the overall response rate is still not high, ranging from $17 \%$ to $60 \%$ [28-37].

Antibody resistance phenomenon exists in so many cases that researchers work hard about it, and a lot of articles have been published. The available methods include combination therapy, that is, the mAb was used plus chemotherapy, or radiation therapy, or other mAbs. In a phase III study of women with HER2-positive breast cancer that treated with trastuzumab, the combination therapy with capecitabine and the multi-tyrosine kinase inhibitor lapatinib, which inhibits both HER2 and EGFR, substantially extended progression-free survival time for 4 months [38]. In a randomized clinical trial, breast cancer patients that progressed after previous trastuzumab therapy were recruited. They were treated with trastuzumab plus capecitabine, which provided significant benefit compared with capecitabine alone [39]; Furthermore, in some cases, antibody resistance was dealt with antiangiogenic agents, e.g. bevacizumab, an anti-VEGF mAb, which can improved the overall survival rate in metastatic colorectal and lung cancers when combined with chemotherapy $[40,41]$, and progression-free survival in metastatic breast and ovarian cancer [42], etc..

In our previous work, an acquired trastuzumab-resistant cell model of human ovarian cancer, SKOV3-T, was established, and IGF-1R molecule was found by microarray analysis and preliminarily testified to be pivotal in cell proliferation. In this study, we confirmed the key role of IGF$1 \mathrm{R}$ in SKOV3-T cells compared to SKOV3 in cell growth/ proliferation, in vitro clone formation, invasion/migration, 
cell cycling and in vivo carcinogenic effect; then a novel anti-IGF-1R human antibody, LMAb1, was prepared and the activity was confirmed to inhibit the carcinogenesis of trastuzumab-resistant ovarian cancer cells both in vitro and in vivo.

\section{Methods \\ Regents}

Trastuzumab (Herceptin ${ }^{\circ}$ was obtained from F. HoffmannLa Roche Ltd.; Antibodies for western blot against EGFR, p-EGFR (Tyr1068), HER2, p-HER2 (Tyr1248), HER3, p-HER3 (Tyr1289), Akt, p-Akt (Ser473), ERK1/2, p-ERK1/2 (Thr202/Tyr204), Src, p-Src (Tyr416), IGF-1R, p-IGF-1R (Tyr1135/Tyr1136), GAPDH and corresponding secondary antibodies were purchased from Cell Signaling Technology; PE conjugated anti-EGFR and anti-HER3, FITC-conjugated Annexin $\mathrm{V}$ antibodies and propidium iodide (PI) were from eBioscience; PE conjugatedanti-HER2 antibody was from BD; Electrophoresis reagents and Hybridization Nitrocellulose Filter membranes were from Bio-Rad; BCA protein assay and enhanced chemiluminescent (ECL) reagents were from Pierce; Cell culture medium Dulbecco's modified Eagle medium (DMEM) and fetal bovine serum (FBS) were purchased from HyClone; Human IGF-1, NRG1- $\beta 1 /$ HRG1- $\beta 1$ was from R \& D; IGF-1R expressing plasmid pCMV6-IGF1R was from OriGene; Lentiviral delivery system was packaged by Gene Pharma (China); MTT [3-(4,5-dimethylthiazol-2-yl)-2,5-diphenyl tetrazolium bromide] and agarose (cell culture level) were purchased from Sigma-Aldrich; Matrigel and Transwell chamber was from Millipore. All other chemicals were obtained from commercial source of analytical grade.

\section{Cell culture}

Human ovarian cancer cell line SKOV3 was from ATCC (American Type Culture Collection, ATCC No. HTB77). The cells were cultivated in DMEM supplemented with 100 units $/ \mathrm{ml}$ penicillin, 100 units $/ \mathrm{ml}$ streptomycin, $10 \% \mathrm{FBS}$ and $4 \mathrm{mM}$ L-glutamine.

Acquired trastuzumab-resistant ovarian cancer cell line SKOV3-T was developed through continuously culturing SKOV3 cells in the presence of $20 \mu \mathrm{g} / \mathrm{ml}$ trastuzumab. Surviving cells were pooled together and tested for dose response to trastuzumab as described before [43]. SKOV3-T cells are now maintained in the presence of $10 \mu \mathrm{g} / \mathrm{ml}$ trastuzumab.

All the cells were incubated in a humidified incubator (Thermo, America) at $37^{\circ} \mathrm{C}$ with $5 \% \mathrm{CO} 2$.

\section{Proliferation assay}

The cells were loaded in 96-well plate with $2 \times 10^{3}$ cells per well with or without various concentration of antibody supplemented with $40 \mathrm{ng} / \mathrm{ml}$ of IGF-1 for 72 hours. Human IgG isotype was added as negative control. The medium was removed from each well and $10 \mu \mathrm{L}$ of CCK- 8 solution was added to $100 \mu \mathrm{L}$ medium in each well for 1-4 hours' incubation at $37^{\circ} \mathrm{C}$. The absorbance was measured at $450 \mathrm{~nm}$ on a Tecan Spectrophotometer (Tecan SPECTRAFluor, Tecan, Männedorf, Switzerland).

\section{Transwell assay}

Cells were digested to a suspension with a density of $1 \times$ $10^{4} / \mathrm{ml}$. Cells were seeded into the transwell chamber (Millipore, USA) which membrane was coated by a dilution of Matrigel $(50 \mathrm{mg} / \mathrm{L})$. The chamber was placed into a 24 well culture plate, with $500 \mu \mathrm{l}$ of DMEM medium containing $10 \%$ serum added outside of the chamber, and $200 \mu \mathrm{l}$ cell suspension were added in the chamber. After $3,6,9,24$ hours, the cells were stained and placed under the fluorescence microscope for observation.

\section{Agar clone formation assay}

Preparation of agarose hydrogels: Agarose was purchased from Sigma-Aldrich, St. Louis, USA. Hydrogel was prepared by dissolving agarose $(0.6 \%, 1.2 \% \mathrm{w} / \mathrm{t})$ in aqueous solvent at the temperature of $90^{\circ} \mathrm{C}$. Once the temperature of this solution is lowered to room temperature, gelation will occur.

Cells were harvested using $0.25 \%$ trypsin. counted, and then loaded in agarose scaffolds. Briefly, cells were suspended in $0.6 \%$ agarose with the cell density of 1000 cells $/ 1000 \mu \mathrm{L}$. The low agarose $(2 \times$ DMEM, $10 \%$ FBS, $1.2 \%$ agarose) molds were allowed to gelation at $4{ }^{\circ} \mathrm{C}$ for $20 \mathrm{~min}$, and then transferred to 6 well culture plate, then add the up agarose $(2 \times$ DMEM, $10 \%$ FBS, $0.6 \%$ agarose) . The plate was placed in incubator containing $5 \% \mathrm{CO} 2$ at $37^{\circ} \mathrm{C}$. As control, cell aggregates were cultured with the same condition as that of experiment group. Culture media were changed every 3 days. Assays were performed at time points of 14 days.

\section{Flow cytometry}

Cells were collected and stained with appropriate PE conjugated antibodies against membrane markers. For each sample, data from approximately 15,000 cells were analyzed using a BD-FACStar ${ }^{\mathrm{m}} \mathrm{instrument}$. Data analysis (the percentage and intensity of stained cells, etc.) was performed on a FACS Calibur flow cytometer using the BD CellQuest ${ }^{\mathrm{Tw}}$ program.

\section{Western blot}

Cell monolayers were washed with cold PBS before they were lysed in cell lysis buffer $(20 \mathrm{mM}$ Tris at pH 7.0, 1\% Triton-X 100, 0.5\% NP-40, $250 \mathrm{mM} \mathrm{NaCl}, 3$ mM EDTA, $3 \mathrm{mM}$ EGTA, $2 \mathrm{mM}$ DTT and protease inhibitor cocktail). Cell lysate supernatants were collected by $12000 \times \mathrm{g}$ centrifugation for 15 minutes at $4 \mathrm{C}^{\circ}$. Total protein concentrations in these fractions were determined by $\mathrm{BCA}$ 
protein assay. The samples were electrophoretically separated on SDS-PAGE and transferred to NC membrane. The membranes were blocked with $5 \%$ non-fat dry milk dissolved in TBST $(10 \mathrm{mM}$ Tris $\mathrm{HCl}, 150 \mathrm{mM} \mathrm{NaCl}$ containing $0.05 \%$ Tween $20, \mathrm{pH} 7.4$ ) for 1 hour before probing overnight at $4{ }^{\circ} \mathrm{C}$ with the appropriate primary antibody (HER1, HER2, HER3, HER4, IGF-1R). In the second day, after washed with TBST three times, the membranes were incubated with HRP-conjugated secondary antibody for 1 hour at room temperature. Signals were detected by X-ray Film following incubation with ECL.

In antibody treating assay, cells were cultivated in 6-well plate and serum starved overnight. In the next day, renew the culture with/without diluted Lmab1 at the concentration of $0.8,4,20 \mu \mathrm{g} / \mathrm{ml}$ or $20 \mu \mathrm{g} / \mathrm{ml}$ of trastuzumab for 4 hours. Then cells were stimulated with $20 \mathrm{ng} / \mathrm{mL}$ of IGF-I for $20 \mathrm{~min}$. Then cells were collected for western blot analysis.

\section{Cell cycle}

Cells were collected by digestion and prepared by fixation in $75 \%$ ethanol overnight (at least 18 hours) at $-20^{\circ} \mathrm{C}$. Then cells were stained with $50 \mu \mathrm{g} / \mathrm{ml} \mathrm{PI} \mathrm{and} 100 \mu \mathrm{g} / \mathrm{ml}$ RNase A for $30 \mathrm{~min}$ at $37^{\circ} \mathrm{C}$ in the dark. Quantification of the cell cycle distribution was done by flow cytometry analysis.

\section{Lentivirus systems for down-regulation of IGF-1R}

The Lentivirus system was used to knock down IGvirusF$1 \mathrm{R}$ expression. The RNAi delivery system was used to deliver shRNAs against IGF-1R as described previously [44].

SKOV3 cells were seeded in a 6-well plate (approximately $5 \times 10^{4}$ cells per well with $2 \mathrm{ml}$ of growth medium). Growth medium was replaced with $2 \mathrm{ml}$ of lentiviral medium containing $8 \mu \mathrm{g} / \mathrm{ml}$ of polybrene at final. After 24 hours, medium was replaced with puromycin-containing growth medium to select transduced cells.

\section{In vivo carcinogenic and immunotherapy assays}

Groups of 5-wk-old female BALB/c athymic, nu/nu (nude) mice were inoculated on fat pad with $2 \times 10^{6} \%$ $0.1 \mathrm{ml} \mathrm{SKOV3}$ or $1 \times 10^{6} / 0.1 \mathrm{ml}$ SKOV3-T cells on day 0 . Since day 7 , mice bearing palpable tumors were randomized into four groups with 6 mice per group $(n=6)$. Then mice were observed twice a week about body weight, survival rates and tumor volumes according to the following equation: Tumor volume $\left(\mathrm{mm}^{3}\right)=1 / 2 \times$ (length) $\times(\text { width })^{2}$. Pairwise differences between groups were compared.

In in vivo immunetherapy assay, mice were inoculated with $1 \times 10^{6} / 0.1 \mathrm{ml}$ SKOV3-T cells. On day 7 , mice were treated i.v. once a week for four times with $5 \mathrm{mg} / \mathrm{kg}$ trastuzumab (group 2), $5 \mathrm{mg} / \mathrm{kg} \mathrm{Lmab1} \mathrm{(group} \mathrm{3),}$
$2.5 \mathrm{mg} / \mathrm{kg}$ Lmab1 (group 4), $5 \mathrm{mg} / \mathrm{kg}$ trastuzumab plus $5 \mathrm{mg} / \mathrm{kg}$ Lmab1 (group 5), $5 \mathrm{mg} / \mathrm{kg}$ trastuzumab and $2.5 \mathrm{mg} / \mathrm{kg} \mathrm{Lmab1}$ (group 6), natural saline (N.S.) were set as negative control (group 1).

Care, in animal assays, we followed the Guidelines for the welfare and use of animals in cancer research. Use and treatment of mice were in strict agreement with international guidelines for the care and use of laboratory animals and approved by Animal Ethics Committee of Institute of Basic Medical Sciences.

\section{Results}

Acquired trastuzumab-resistant SKOV3-T cells grow faster than SKVO3

Human ovarian cancer SKOV3 cells, which over express HER2, werecultured continuously for 8 months in the presence of $10 \mu \mathrm{g} / \mathrm{ml}$ trastuzumab, resulting in the acquisition of trastuzumab resistance in the surviving cell population. Compared with the parental cells, the resistant SKOV3 cells had a significant higher viability or proliferative capacity in cell proliferation assay (Figure 1A) in 96-well plate and cell counting assay (Figure 1B); meanwhile, SKOV3-Tdisplayeddramatically increased colony formation on the agar cloning assay, for the clones were obviously bigger and much more than SKOV3 (Figure 1C); furthermore, in transwell assays, SKOV3-T exhibited stronger migration capacity, for after 24 hours, about 626 SKOV3-T cells moved while only less than 100 SKOV3 cells moved across the well (Figure 1D); furthermore, in in vivo carcinogenic assay, the mean volume of SKOV3-T transplanted tumor was significantly larger than SKOV3 (Figure 1E). These results suggest that trastuzumab-resistant ovarian cancer cells SKOV3-T growth much faster and migrate better than SKOV3, suggesting stronger malignancy and metastasis character of SKOV3-Tin vivo than non-resistant cells.

\section{IGF-1R can promote the proliferation of SKOV3}

According to our previous work, based on the mRNA array analysis, IGF-1R up-regulation (Figure 2A) was proved to play a key role in SKOV3-T proliferation in vitro. To the opposite, the expression level of HER2 in SKOV3-T was dramatically lower than SKOV3by flow cytometry method (Figure 2A).To further examine the role of IGF-1R in ovarian cancer cells, IGF-1R-pCMV6 plasmid, a eukaryotic expression vector subcloned with full IGF-1R exon sequence, was transfected into SKOV3 using lipofectamine 2000, generating a pool of IGF-1Rpositive SKOV3 cells (Figure 2B). As shown in Figure 2C, the transfected cells had much higher viability or proliferative capacity than SKOV3; meanwhile, they also displayed increased colony formation capacity (Figure 2D); furthermore, according to the cell cycling assay, SKOV3IGF-1R cells (pool) has S-phase cells than SKOV3, 


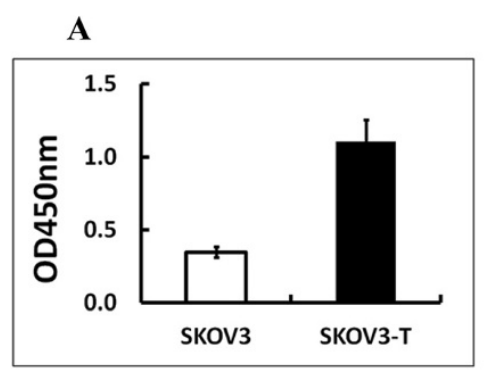

B

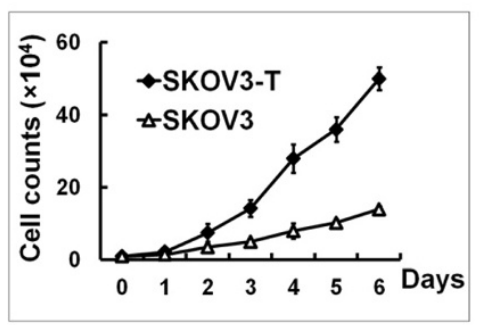

C

SKOV3

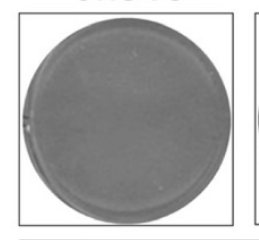

SKOV3-T
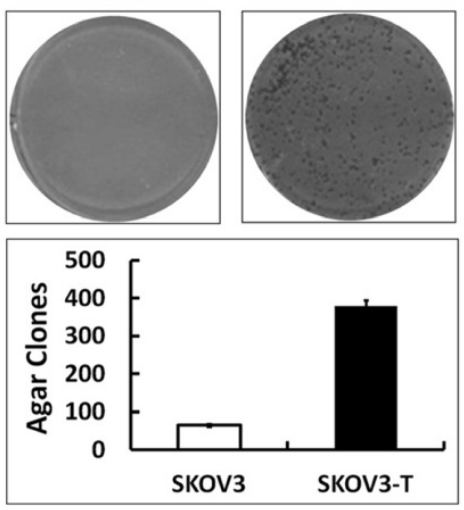

Figure 1 Acquired trastuzumab-resistant cell line SKOV3-T cells grow faster than SKOV3. SKOV3 cells were cultivated for 8 months in the presence of $20 \mathrm{\mu g} / \mathrm{ml}$ trastuzumab continuously to obtain SKOV3-T cells. The comparison of SKOV3-T and parental SKOV3 cells by (A) cell proliferation, (B) cell counting, (C) agar clone formation, (D) transwell, and (E) in vivo carcinogenic assays. In cell counting assays, cells were cultured in day 0 at the start concentration of $1 \times 10^{4}$ per 24-well, and in day 1 to day 6 , the cells were digested everyday and the whole cell number was counted. The trastuzumab-resistant SKOV3-T seemed to have significantly enhanced cell growth/proliferation, clone formation, stronger invasion and migration character both in vitro and in vivo versus non-resistant SKOV3 cells.

suggesting much quicker cell multiplication rate of SKOV3-IGF-1Rcells (Figure 2E); in in vivo tumor formation assay, IGF-1R positive cells exhibited more rapid growth capacity than parental cells (Figure 2F), indicating thatIGF-1R can promote the proliferation of SKOV3. All above demonstrated the importance of membrane IGF-1R as well as its downstream cascade in retaining/ promoting the survival of SKOV3-T, especially when HER2-related signal pathway was down-regulated.

\section{IGF-1R knockdown by shRNA could inhibit the proliferation of SKOV3-T}

As shown above, IGF-1R could fasten the cell growth of SKOV3, which was similar to the quick growth of
SKOV3-T. In order to further analyze the biofunction(s) of IGF-1R in SKOV3-T cells, a lentivirus vector to knock down IGF-1R was packed and transduced into SKOV3$\mathrm{T}$ cells, while cells transduced with virus CON054 were set as negative control. As shown in Figure 3A, IGF-1R expression was inhibited according to flow cytometry and western blot analysis. Furtherly, cell proliferation assay showed that SKOV3-T KD cells grow more slowly than SKOV3-T (Figure 3B); similarly, the agar clone formation capacity of SKOV3-T KD cells was weaker (Figure 3C); meanwhile, in the cell cycling assay shown in Figure 3D, SKOV3-T KD exhibited less S-phase cells (28.84\%) than SKOV3-T (31.23\%), indicating thatIGF$1 \mathrm{R}$ could affect the cell cycle, thus influence the cell 
A

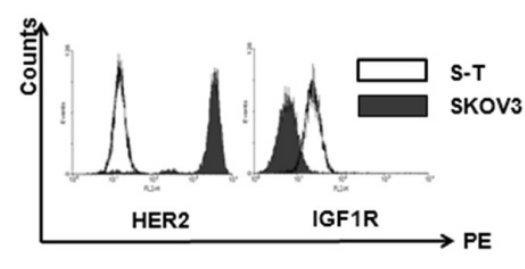

B
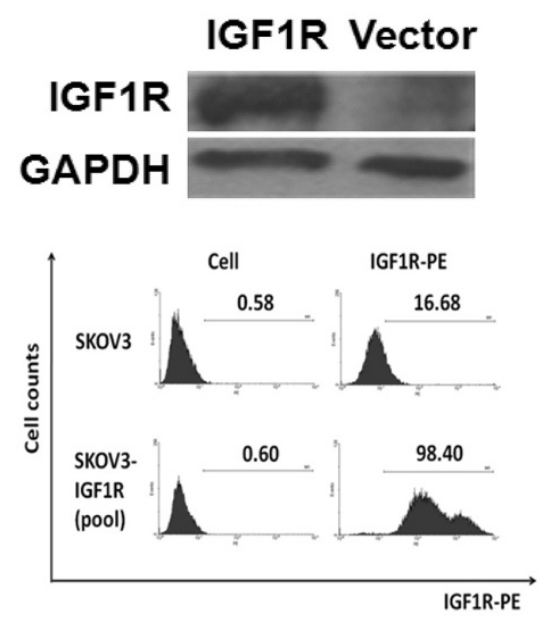

C

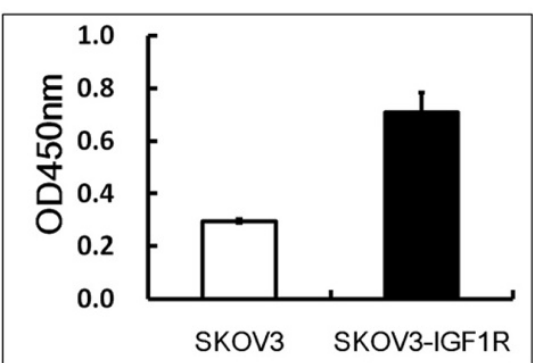

D

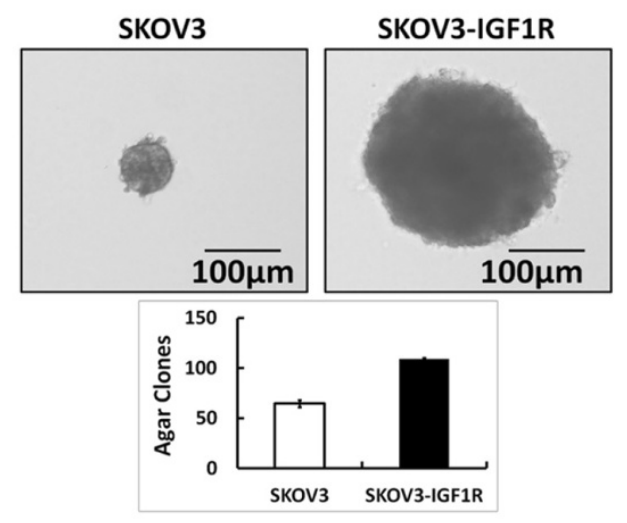

$\mathbf{E}$

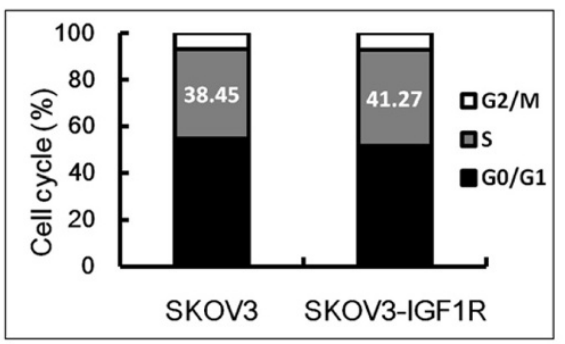

F

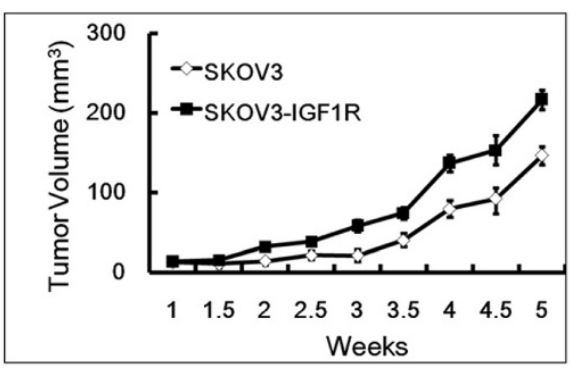

Figure 2 IGF-1R can promote the proliferation of SKOV3. (A) IGF-1R expression was up-regulated in SKOV3-T while HER2 was opposite by flow cytometry analysis; (B) IGF-1R-positive SKOV3 cell preparation by eukaryotic transfection with pCMV6-IGF-1R plasmid. Cell proliferation (C) and agar clone formation (D) assays both indicated the enhanced carcinogenic activity of IGF-1R-positive SKOV3 cells, while according to cell cycle analysis (E), SKOV3-IGF1R owned more S-phase cells in order to multiply quicker; Similarly, in vivo tumor model (F) further displayed more rapid tumor growth of SKOV3-IGF1R, indicating that IGF-1R can promote the cell survival and multiplication in ovarian cancer SKOV3 cells. To be clear, in this figure, "SKOV3" sample means original pCMV6 transfected cells.

proliferation of SKOV3-T. Further in vivo experiment also displayed the importance of IGF-1R in SKOV3-T, for the mean tumor volume of SKOV3-T was $\sim 1257 \mathrm{~mm}^{3}$, while SKOV3 KD was $\sim 1115 \mathrm{~mm}^{3}$ (Figure 3E).

\section{Anti-IGF-1R mAb (LMAb1) could inhibit the proliferation of SKOV3-T}

Since the trastuzumab resistant SKOV3-T cells have higher IGF-1R level than parental SKOV3 cells, a novel anti-IGF-1R mAb, named as LMAb1, was screened out from a natural fully human phage library in our lab
(Chinese patent: 201410271608.8). Here, in SKOV3-T cells, LMAb1 could inhibit cell proliferation, for in $10 \mu \mathrm{g} / \mathrm{ml}$ LMAb1 treated samples, cell survival rate was $\sim 75 \%$ contrasting to non-treated groups (Figure $4 \mathrm{~A}$ ); meanwhile, the agar clone formation of SKOV3-T was also inhibited by LMAb1. When the concentration of antibody reached $50 \mu \mathrm{g} / \mathrm{ml}$, the average clone number was $\sim 757$ contrasting to $\sim 1102$ of SKOV3-T (Figure $4 B$ ); furthermore, in transwell assay, the migration capacity was inhibited on a dose dependent manner, for after 15 hours, about 300 SKOV3-T cells per well were 


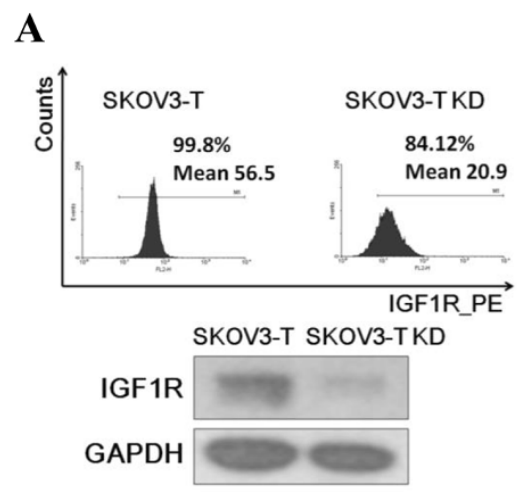

B

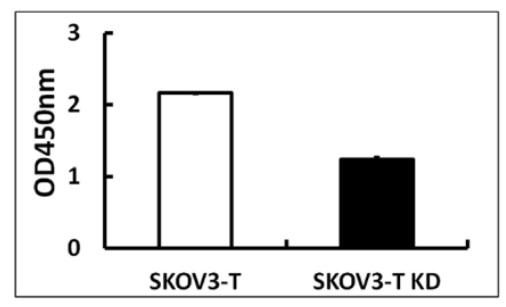

C

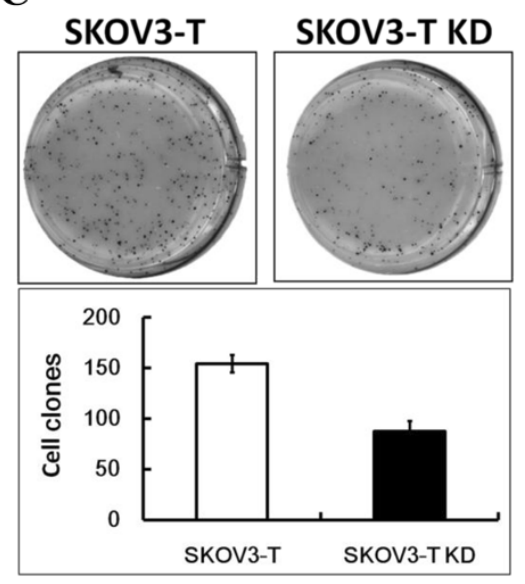

D

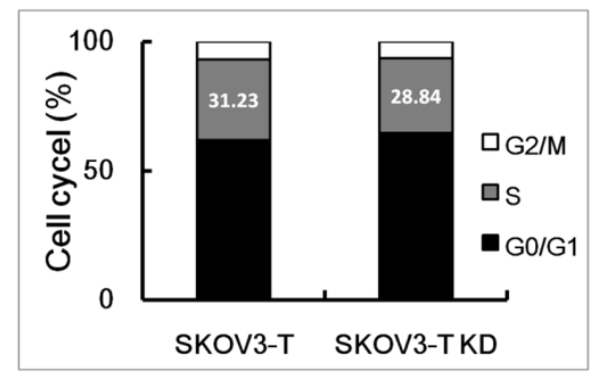

$\mathbf{E}$

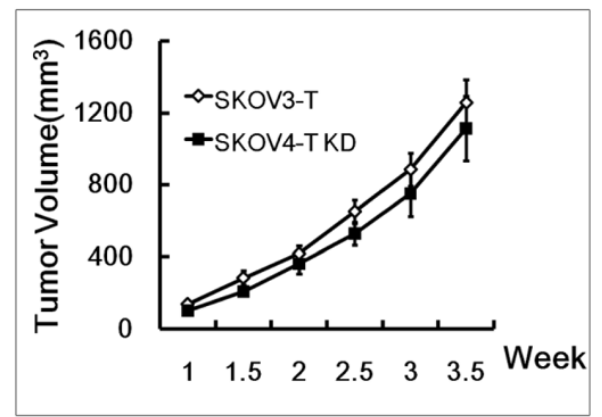




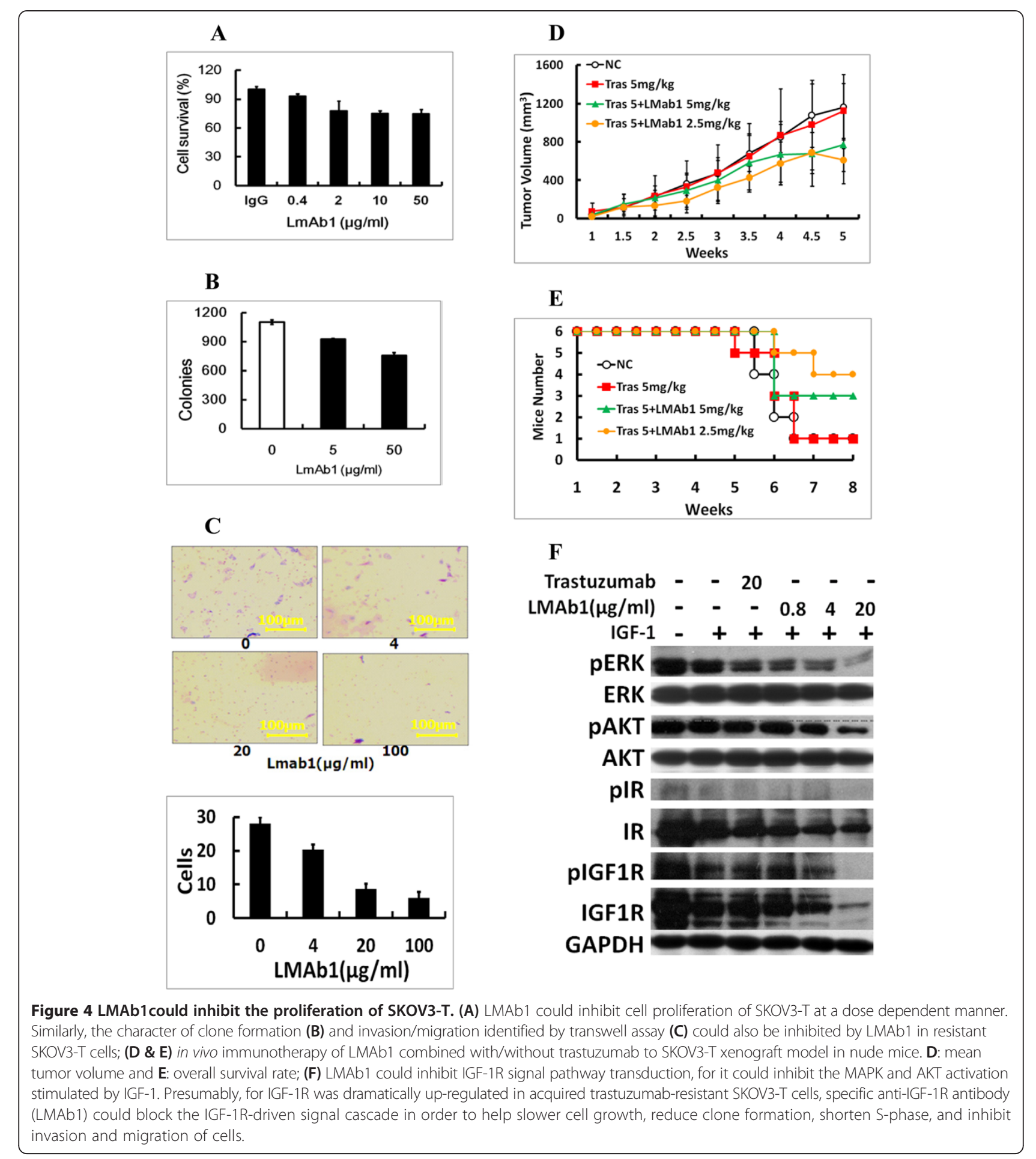

plus trastuzumab treated mice survived, while there was only one or fewer mice was still alive in other groups. For the IGF-1R is essentially expressed by most organs and tissues, therefore anti-IGF-1R antibody such as LMAb1 might have side-effects, which may influence the survival rate of mice as well as the anti-tumor effects. According to the cell signaling assays shown in Figure 4F, LMAb1 could block the IGF-1 induced activation of pERK, pAKT and PIGF-1R along with the increase concentration of LMAb1, indicating that inhibition of PI3K-AKT as well as MAPK cascade might be one of the anti-tumor mechanisms of anti-IGF-1R antibody LMAb1. 


\section{Discussion}

There are more and more antibody resistance clinical cases, while many patients with cancer do not respond to antibody treatment (de novo resistance). More and more patients who receive antibody treatment have the problem of the relapse and antibody resistance (acquired resistance). Some acquired antibody resistant cases showed low recurrence-free survival, cancer-related survival, and/ or overall survival (OS), and high risk of local and distant recurrence.

Type I insulin-like growth factor receptor (IGF-1R) has been founded for decades for its role in growth and tumorigenesis [45]. Not until recently had advances in medicinal chemistry and biotechnology provided the tools for targeting the insulin-like growth factor (IGF) pathway in patients. IGF-1R belongs to the insulin receptor (IR) family that includes the IR, IGF-1R, IGF-1R/ IR, and the mannose 6-phosphate receptor (also known as IGF-2R). IGF-1R can be activated by the ligands insulinlike growth factor-1 (IGF-1) or insulin-like growth factor2 (IGF-2). Intracellular signaling of IGF-1R is mediated through IR substrates and Src-homology collagen protein (Shc) [46], which leads to activation of the mitogenactivated protein kinase (MAPK) pathway and the PI3KAKT pathway [47]. IGF-1R is ubiquitously expressed in normal tissues and plays an important role in growth and various physiological functions, including those involving the cardiac and neurological systems, as well as glucose homeostasis. The influence on glucose probably occurs through feedback down-regulation of HGH by circulating IGF-1 and the local effect of IGF-1 on IGF-1R in the muscles or kidneys to promote glucose uptake $[48,49]$.

Extensive in vitro and in vivo studies have implicated IGF-1R, IGF-1, and IGF-2 signaling in cancer development, progression, and maintenance. IGF-1R expression is critical for anchorage-independent growth, a well identified property of cancer cells. IGF-1 and IGF-2 are strong mitogens in a variety of cancer cell lines, including breast cancer [50-53], colon cancer [54,55], prostate cancer [56], and myeloma [57]. High circulating levels of IGF-1 have been associated with increased risk of prostate, breast, and colon cancers [45]. The IGF/IGF-1R pathway have been shown to have extensive cross-talk with the epidermal growth factor receptor (EGFR), estrogen receptor (ER) and human epidermal growth factor receptor 2 (HER2) signaling pathways and to play an important role in the resistance mechanisms of EGFR/ HER2-targeted agents and cytotoxic drugs [58]. Recent work also indicated a potential role for IGF-1R in the resistance to RAF-MEK inhibitors [59] and mTOR inhibitors [60], however, there were rare report to show the importance of IGF-1R in antibody-resistant cases. IGF-1R can be founded in most solid tumors and hematological malignancies examined to date, and IGF-2 overexpression,
IGFBP modulations, and IGF-2R down-regulation have also been founded in cancer cells $[46,61,62]$. Nevertheless, unlike other growth factor receptors such as EGFR and HER-2, activating mutations of the IGF-1R gene have not been reported, and gene amplification is rare in the tumors that have been tested [63]. On the other hand, several genetic abnormalities can lead indirectly to IGF/IGF$1 \mathrm{R}$ overexpression and signaling. Some tumors, including hepatocellular carcinoma and breast cancer, have been associated with loss of heterozygosity of the IGF2R gene [64]. Loss of imprinting of IGF-2, first described in Wilms tumor, has since been identified in adult tumors and is associated with an increased risk of colon cancer $[65,66]$. These genetic changes may increase IGF-2 production or its bioavailability for IGF-1R signaling.

At least seven human or humanized anti-IGF-1R mAbs entered clinical trials: Cixutumumab [67-69], Figitumumab [70-74], Dalotuzumab [75-77], Ganitumab [78-81], R1507 [82], SCH. 717454 [83], AVE1642 [84,85] and BIIB022 [86], etc.. Common mechanisms of antibody action include blockade of the receptor from ligand binding and internalization/degradation of IGF-1R [87]. In addition, anti-IGF1R mAbs also down-regulate the IGF-1R/IR hybrid receptor [88]. Common treatment have emerged adverse events that include hyperglycemia.

IGF-1R signaling has been causally linked to de novo or acquired resistance to trastuzumab and EGFR-targeting agents in a lot of models. In vitro and in vivo tumor models have also demonstrated direct interactions between IGF1R, EGFR/HER-2 [61,85-88], and co-localization of IGF-1R and HER-2. Treatment of resistant cells with IGF-1R inhibitors was shown to inhibit transactivation of HER2 and restore sensitivity to trastuzumab [89].

Our previous study reported the trastuzumab-resistant ovarian cancer cells, SKOV3-T, with lower HER2 and higher IGF-1R and HER3 expression level than parent SKOV3 cells. The two new biomarkers were suggested to be important in maintaining the cell growth [43]. According to our work, in SKOV3-T cells, epitope escaping might exist during long-term treatment with trastuzumab, which was possibly the main reason why SKOV3-T possessed resistant capacity to trastuzumab. When full length of HER2 gene was transfected into SKOV3-T, the sensitivity to trastuzumab could be recovered (data not shown); meanwhile, the IGF-1R expression level was upregulated in SKOV3-T cells, which should be important to keep cell survival at the absence of HER2 (Figure 1). Here, we identified the role of IGF-1R in cell growth/ proliferation, migration, cell cycling, clone formation, and in vivo carcinogenic character (Figures 2 and 3); Based on the data above, we prepared an IGF-1R mAb called LMAb1 to treat SKOV3-T. LMAb1 showed curative effect against the resistant cells; In vivo assays showed its effective anti-tumor function, especially when 
being used in combination with trastuzumab, which was beneficial to higher survival rate of mice as well as smaller tumor. It was inferred that trastuzumab might ease the side-effect of LMAb1 in vivo with unknown reason, for mice treated with LMAb1 only didn't contribute to obvious longer survival time, although the tumor volume was indeed smaller than control group(s); besides, we also evidenced preliminarily that the mechanism of antibody included the inhibition of IGF-1R and downstream MAPK, AKT pathway activation (Figure 4). Similarly, we also use LMAb1 to treat MCF-7 cells, an IGF-1R-positive breast cancer cell line, which showed satisfactory anti-tumor activity by flow cytometry, cell proliferation and transwell in vitro (data not show).

\section{Conclusion}

In conclusion, we achieved satisfactory anti-tumor activity with combination therapy strategy, e.g. trastuzumab plus anti-IGF-1R mAb (LMAb1), in trastuzumab-resistant ovarian cancer model. According to our work, it should be inferred that in similar cases with resistance to a single antibody drug, not only acquired but also de novo, combination therapeutic strategies might achieve better curative effect.

\section{Competing interests}

The authors declare that they have no competing interests.

\section{Authors' contributions}

W carried out cell cloning, transwell and immunotherapy assays in vivo, ZY did cell cycling analysis and helped do in vivo carcinogenic assays, LM cultured cells and did clone screening, F did virus infection, P established the resistant cell line SKOVZ-T, G did western blot assays, LZ participated in cell cultivation, ZT analyzed the results statistically, LX analyzed flow cytometry assays. $\mathrm{S}$ revised the manuscript, $\mathrm{M}$ helped design the study and draft the manuscript, Q designed the studies and prepared the MS. All authors have read and approved this final manuscript.

\section{Acknowledgements}

This work was supported by National Natural Sciences Foundation of China grant (No. 31370938, No.81272528, No. 30873083 and No. 81173082), National High Technology Research and Development Program (863 program, No. 2012AA02A302).

\section{Author details \\ 'Laboratory of Cellular and Molecular Immunology, Institute of Immunology, Henan University, Kaifeng 475001, China. ${ }^{2}$ Laboratory of Immunology, Institute of Basic Medical Sciences, PO Box 130(3), Taiping Road \#27, Beijing 100850, China. ${ }^{3}$ Department of Gynecology and Obstetrics, PLA General Hospital, Fuxing Road No. 28, Beijing 100853, China. ${ }^{4}$ Department of Environment and Pharmacy, Tianjin Institute of Health and Environmental Medicine, Beijing 100850, China.}

Received: 29 July 2014 Accepted: 23 October 2014

Published online: 26 November 2014

\section{References}

1. Raval RR, Sharabi AB, Walker AJ, Drake CG, Sharma P: Tumor immunology and cancer immunotherapy: summary of the 2013 SITC primer. $J$ Immunother Cancer 2014, 2:14.

2. Slichenmyer WJ, Fry DW: Anticancer therapy targeting the erbB family of receptor tyrosine kinases. Semin Oncol 2001, 28:67-79.

3. Schmidt M, Lewark B, Kohlschmidt N, Glawatz C, Steiner E, Tanner B, Pilch H, Weikel W, Kolbl H, Lehr HA: Long-term prognostic significance of HER-2/ neu in untreated node-negative breast cancer depends on the method of testing. Breast Cancer Res 2005, 7:R256-R266.

4. Ross JS, Fletcher JA: The HER-2/neu oncogene in breast cancer: prognostic factor, predictive factor, and target for therapy. Oncologist 1998, 3:237-252.

5. Ladjemi MZ, Jacot W, Chardes T, Pelegrin A, Navarro-Teulon I: Anti-HER2 vaccines: new prospects for breast cancer therapy. Cancer Immunol Immunother 2010, 59:1295-1312.

6. Hynes NE, Stern DF: The biology of erbB-2/neu/HER-2 and its role in cancer. Biochim Biophys Acta 1994, 1198:165-184.

7. Clynes RA, Towers TL, Presta LG, Ravetch JV: Inhibitory Fc receptors modulate in vivo cytotoxicity against tumor targets. Nat Med 2000, 6:443-446.

8. Gennari R, Menard S, Fagnoni F, Ponchio L, Scelsi M, Tagliabue E, Castiglioni F, Villani L, Magalotti C, Gibelli N, Oliviero B, Ballardini B, Da Prada G, Zambelli A, Costa A: Pilot study of the mechanism of action of preoperative trastuzumab in patients with primary operable breast tumors overexpressing HER2. Clin Cancer Res 2004, 10:5650-5655.

9. Arnould L, Gelly M, Penault-Llorca F, Benoit L, Bonnetain F, Migeon C, Cabaret V, Fermeaux V, Bertheau P, Garnier J, Jeannin JF, Coudert B: Trastuzumab-based treatment of HER2-positive breast cancer: an antibody-dependent cellular cytotoxicity mechanism? Br J Cancer 2006, 94:259-267.

10. Piccart-Gebhart MJ, Procter M, Leyland-Jones B, Goldhirsch A, Untch M, Smith I, Gianni L, Baselga J, Bell R, Jackisch C, Cameron D, Dowsett M, Barrios CH, Steger G, Huang CS, Andersson M, Inbar M, Lichinitser M, Lang I, Nitz U, Iwata H, Thomssen C, Lohrisch C, Suter TM, Ruschoff J, Suto T, Greatorex V, Ward C, Straehle C, McFadden E, Dolci MS, Gelber RD: Trastuzumab after adjuvant chemotherapy in HER2-positive breast cancer. N Engl J Med 2005, 353:1659-1672.

11. Mullen P, Cameron DA, Hasmann M, Smyth JF, Langdon SP: Sensitivity to pertuzumab (2C4) in ovarian cancer models: cross-talk with estrogen receptor signaling. Mol Cancer Ther 2007, 6:93-100.

12. Agus DB, Akita RW, Fox WD, Lewis GD, Higgins B, Pisacane PI, Lofgren JA, Tindell C, Evans DP, Maiese K, Scher HI, Sliwkowski MX: Targeting ligandactivated ErbB2 signaling inhibits breast and prostate tumor growth. Cancer Cell 2002, 2:127-137.

13. Jackson JG, St Clair P, Sliwkowski MX, Brattain MG: Blockade of epidermal growth factor- or heregulin-dependent ErbB2 activation with the antiErbB2 monoclonal antibody $2 \mathrm{C} 4$ has divergent downstream signaling and growth effects. Cancer Res 2004, 64:2601-2609.

14. Nahta R, Hung MC, Esteva FJ: The HER-2-targeting antibodies trastuzumab and pertuzumab synergistically inhibit the survival of breast cancer cells. Cancer Res 2004, 64:2343-2346.

15. Takai N, Jain A, Kawamata N, Popoviciu LM, Said JW, Whittaker S, Miyakawa I, Agus DB, Koeffler HP: 2C4, a monoclonal antibody against HER2, disrupts the HER kinase signaling pathway and inhibits ovarian carcinoma cell growth. Cancer 2005, 104:2701-2708.

16. Teicher BA, Doroshow JH: The promise of antibody-drug conjugates. $N$ Engl J Med 2012, 367:1847-1848.

17. Verma S, Miles D, Gianni L, Krop IE, Welslau M, Baselga J, Pegram M, Oh DY, Dieras V, Guardino E, Fang L, Lu MW, Olsen S, Blackwell K: Trastuzumab emtansine for HER2-positive advanced breast cancer. N Engl J Med 2012, 367:1783-1791.

18. Tagliabue E, Campiglio M, Pupa SM, Menard S, Balsari A: Activity and resistance of trastuzumab according to different clinical settings. Cancer Treat Rev 2012, 38:212-217.

19. Piccart M: Circumventing de novo and acquired resistance to trastuzumab: new hope for the care of ErbB2-positive breast cancer. Clin Breast Cancer 2008, 8(Suppl 3):S100-S113.

20. Liebisch P, Eppinger S, Schopflin C, Stehle G, Munzert G, Dohner H, Schmid $\mathrm{M}: \mathrm{CD} 44 \mathrm{v} 6$, a target for novel antibody treatment approaches, is frequently expressed in multiple myeloma and associated with deletion of chromosome arm 13q. Haematologica 2005, 90:489-493.

21. Richardson PG, Sonneveld P, Schuster MW, Irwin D, Stadtmauer EA, Facon T, Harousseau JL, Ben-Yehuda D, Lonial S, Goldschmidt H, Reece D, San-Miguel JF, Blade J, Boccadoro M, Cavenagh J, Dalton WS, Boral AL, Esseltine DL, Porter JB, Schenkein D, Anderson KC: Bortezomib or high-dose dexamethasone for relapsed multiple myeloma. N Engl J Med 2005, 352:2487-2498.

22. Saltz LB, Meropol NJ, Loehrer PJ Sr, Needle MN, Kopit J, Mayer RJ: Phase II trial of cetuximab in patients with refractory colorectal cancer that 
expresses the epidermal growth factor receptor. J Clin Oncol 2004, 22:1201-1208.

23. Cunningham D, Humblet $Y$, Siena $S$, Khayat $D$, Bleiberg $H$, Santoro A, Bets $D$, Mueser M, Harstrick A, Verslype C, Chau I, Van Cutsem E: Cetuximab monotherapy and cetuximab plus irinotecan in irinotecan-refractory metastatic colorectal cancer. N Engl J Med 2004, 351:337-345.

24. Lenz HJ, Van Cutsem E, Khambata-Ford S, Mayer RJ, Gold P, Stella P, Mirtsching B, Cohn AL, Pippas AW, Azarnia N, Tsuchihashi Z, Mauro DJ, Rowinsky EK: Multicenter phase II and translational study of cetuximab in metastatic colorectal carcinoma refractory to irinotecan, oxaliplatin, and fluoropyrimidines. J Clin Oncol 2006, 24:4914-4921.

25. Van Cutsem E, Peeters M, Siena S, Humblet Y, Hendlisz A, Neyns B, Canon $J$, Van Laethem JL, Maurel J, Richardson G, Wolf M, Amado RG: Open-label phase III trial of panitumumab plus best supportive care compared with best supportive care alone in patients with chemotherapy-refractory metastatic colorectal cancer. J Clin Oncol 2007, 25:1658-1664.

26. Allegra CJ, Jessup JM, Somerfield MR, Hamilton SR, Hammond EH, Hayes DF, McAllister PK, Morton RF, Schilsky RL: American Society of Clinical Oncology provisional clinical opinion: testing for KRAS gene mutations in patients with metastatic colorectal carcinoma to predict response to anti-epidermal growth factor receptor monoclonal antibody therapy. J Clin Oncol 2009, 27:2091-2096.

27. Morton RF, Hammond EH: ASCO provisional clinical opinion: KRAS, cetuximab, and panitumumab-clinical implications in colorectal cancer. J Oncol Pract 2009, 5:71-72

28. Sartore-Bianchi A, Di Nicolantonio F, Nichelatti M, Molinari F, De Dosso S, Saletti P, Martini M, Cipani T, Marrapese G, Mazzucchelli L, Lamba S, Veronese S, Frattini M, Bardelli A, Siena S: Multi-determinants analysis of molecular alterations for predicting clinical benefit to EGFR-targeted monoclonal antibodies in colorectal cancer. PLoS One 2009, 4:e7287.

29. Di Fiore F, Blanchard F, Charbonnier F, Le Pessot F, Lamy A, Galais MP, Bastit L, Killian A, Sesboue R, Tuech JJ, Queuniet AM, Paillot B, Sabourin JC, Michot $F$, Michel P, Frebourg T: Clinical relevance of KRAS mutation detection in metastatic colorectal cancer treated by Cetuximab plus chemotherapy. Br J Cancer 2007, 96:1166-1169.

30. De Roock W, Piessevaux H, De Schutter J, Janssens M, De Hertogh G, Personeni N, Biesmans B, Van Laethem JL, Peeters M, Humblet Y, Van Cutsem E, Tejpar S: KRAS wild-type state predicts survival and is associated to early radiological response in metastatic colorectal cancer treated with cetuximab. Ann Oncol 2008, 19:508-515.

31. Karapetis CS, Khambata-Ford S, Jonker DJ, O'Callaghan CJ, Tu D, Tebbutt NC, Simes RJ, Chalchal H, Shapiro JD, Robitaille S, Price TJ, Shepherd L, Au HJ, Langer C, Moore MJ, Zalcberg JR: K-ras mutations and benefit from cetuximab in advanced colorectal cancer. N Engl J Med 2008, 359:1757-1765.

32. Lievre A, Bachet JB, Boige V, Cayre A, Le Corre D, Buc E, Ychou M, Bouche $O$, Landi B, Louvet C, Andre T, Bibeau F, Diebold MD, Rougier P, Ducreux M, Tomasic G, Emile JF, Penault-Llorca F, Laurent-Puig P: KRAS mutations as an independent prognostic factor in patients with advanced colorectal cancer treated with cetuximab. J Clin Oncol 2008, 26:374-379.

33. Freeman DJ, Juan T, Reiner M, Hecht JR, Meropol NJ, Berlin J, Mitchell E, Sarosi I, Radinsky R, Amado RG: Association of K-ras mutational status and clinical outcomes in patients with metastatic colorectal cancer receiving panitumumab alone. Clin Colorectal Cancer 2008, 7:184-190.

34. Amado RG, Wolf M, Peeters M, Van Cutsem E, Siena S, Freeman DJ, Juan T, Sikorski R, Suggs S, Radinsky R, Patterson SD, Chang DD: Wild-type KRAS is required for panitumumab efficacy in patients with metastatic colorectal cancer. J Clin Oncol 2008, 26:1626-1634.

35. Perkins G, Lievre A, Ramacci C, Meatchi T, de Reynies A, Emile JF, Boige V, Tomasic G, Bachet JB, Bibeau F, Bouche O, Penault-Llorca F, Merlin JL, Laurent-Puig P: Additional value of EGFR downstream signaling phosphoprotein expression to KRAS status for response to anti-EGFR antibodies in colorectal cancer. Int J Cancer 2010, 127:1321-1331.

36. Lievre A, Bachet JB, Le Corre D, Boige V, Landi B, Emile JF, Cote JF, Tomasic G, Penna C, Ducreux M, Rougier P, Penault-Llorca F, Laurent-Puig P: KRAS mutation status is predictive of response to cetuximab therapy in colorectal cancer. Cancer Res 2006, 66:3992-3995.

37. Saridaki Z, Tzardi M, Papadaki C, Sfakianaki M, Pega F, Kalikaki A, Tsakalaki E, Trypaki M, Messaritakis I, Stathopoulos E, Mavroudis D, Georgoulias V, Souglakos J: Impact of KRAS, BRAF, PIK3CA mutations, PTEN, AREG, EREG expression and skin rash in $>/=2$ line cetuximab-based therapy of colorectal cancer patients. PLoS One 2011, 6:e15980.
38. Geyer CE, Forster J, Lindquist D, Chan S, Romieu CG, Pienkowski T, JagielloGruszfeld A, Crown J, Chan A, Kaufman B, Skarlos D, Campone M, Davidson N, Berger M, Oliva C, Rubin SD, Stein S, Cameron D: Lapatinib plus capecitabine for HER2-positive advanced breast cancer. N Engl J Med 2006, 355:2733-2743.

39. von Minckwitz G, du Bois A, Schmidt M, Maass N, Cufer T, de Jongh FE, Maartense E, Zielinski C, Kaufmann M, Bauer W, Baumann KH, Clemens MR, Duerr R, Uleer C, Andersson M, Stein RC, Nekljudova V, Loibl S: Trastuzumab beyond progression in human epidermal growth factor receptor 2-positive advanced breast cancer: a german breast group 26/ breast international group 03-05 study. J Clin Oncol 2009, 27:1999-2006.

40. Hurwitz H, Fehrenbacher L, Novotny W, Cartwright T, Hainsworth J, Heim W, Berlin J, Baron A, Griffing S, Holmgren E, Ferrara N, Fyfe G, Rogers B, Ross R, Kabbinavar F: Bevacizumab plus irinotecan, fluorouracil, and leucovorin for metastatic colorectal cancer. N Engl J Med 2004, 350:2335-2342.

41. Sandler A, Gray R, Perry MC, Brahmer J, Schiller JH, Dowlati A, Lilenbaum R, Johnson DH: Paclitaxel-carboplatin alone or with bevacizumab for non-small-cell lung cancer. N Engl J Med 2006, 355:2542-2550.

42. Valachis A, Polyzos NP, Patsopoulos NA, Georgoulias V, Mavroudis D, Mauri $D$ : Bevacizumab in metastatic breast cancer: a meta-analysis of randomized controlled trials. Breast Cancer Res Treat 2010, 122:1-7.

43. Jia Y, Zhang Y, Qiao C, Liu G, Zhao Q, Zhou T, Chen G, Li Y, Feng J, Zhang Q, Peng H: IGF-1R and ErbB3/HER3 contribute to enhanced proliferation and carcinogenesis in trastuzumab-resistant ovarian cancer model. Biochem Biophys Res Commun 2013, 436:740-745.

44. Yang T, Burrows C, Park JH: Development of a doxycycline-inducible lentiviral plasmid with an instant regulatory feature. Plasmid 2014, 72:29-35.

45. Pollak M: Insulin and insulin-like growth factor signalling in neoplasia. Nat Rev Cancer 2008, 8:915-928.

46. Baserga R: The IGF-I receptor in cancer research. Exp Cell Res 1999, 253:1-6.

47. Pollak MN, Schernhammer ES, Hankinson SE: Insulin-like growth factors and neoplasia. Nat Rev Cancer 2004, 4:505-518.

48. Clemmons DR: Involvement of insulin-like growth factor-I in the control of glucose homeostasis. Curr Opin Pharmacol 2006, 6:620-625.

49. LeRoith D, Yakar S: Mechanisms of disease: metabolic effects of growth hormone and insulin-like growth factor 1. Nat Clin Pract Endocrinol Metab 2007, 3:302-310.

50. Cullen KJ, Yee D, Sly WS, Perdue J, Hampton B, Lippman ME, Rosen N: Insulin-like growth factor receptor expression and function in human breast cancer. Cancer Res 1990, 50:48-53.

51. Gooch JL, Van Den Berg CL, Yee D: Insulin-like growth factor (IGF)-I rescues breast cancer cells from chemotherapy-induced cell death-proliferative and anti-apoptotic effects. Breast Cancer Res Treat 1999, 56:1-10.

52. Lee AV, Yee D: Insulin-like growth factors and breast cancer. Biomed Pharmacother 1995, 49:415-421.

53. Peyrat JP, Bonneterre J: Type 1 IGF receptor in human breast diseases. Breast Cancer Res Treat 1992, 22:59-67.

54. Hassan AB, Macaulay VM: The insulin-like growth factor system as a therapeutic target in colorectal cancer. Ann Oncol 2002, 13:349-356.

55. Wu Y, Yakar S, Zhao L, Hennighausen L, LeRoith D: Circulating insulin-like growth factor-I levels regulate colon cancer growth and metastasis. Cancer Res 2002, 62:1030-1035.

56. Nickerson T, Chang F, Lorimer D, Smeekens SP, Sawyers CL, Pollak M: In vivo progression of LAPC- 9 and LNCaP prostate cancer models to androgen independence is associated with increased expression of insulin-like growth factor I (IGF-I) and IGF-I receptor (IGF-IR). Cancer Res 2001, 61:6276-6280.

57. Ge NL, Rudikoff S: Insulin-like growth factor I is a dual effector of multiple myeloma cell growth. Blood 2000, 96:2856-2861.

58. Gee JM, Robertson JF, Gutteridge E, Ellis IO, Pinder SE, Rubini M, Nicholson RI: Epidermal growth factor receptor/HER2/insulin-like growth factor receptor signalling and oestrogen receptor activity in clinical breast cancer. Endocr Relat Cancer 2005, 12(Suppl 1):S99-S111.

59. Villanueva J, Vultur A, Lee JT, Somasundaram R, Fukunaga-Kalabis M, Cipolla AK, Wubbenhorst B, Xu X, Gimotty PA, Kee D, Santiago-Walker AE, Letrero R, D'Andrea K, Pushparajan A, Hayden JE, Brown KD, Laquerre S, McArthur GA, Sosman JA, Nathanson KL, Herlyn M: Acquired resistance to BRAF inhibitors mediated by a RAF kinase switch in melanoma can be overcome by cotargeting MEK and IGF-1R/PI3K. Cancer Cell 2010, 18:683-695. 
60. Shin DH, Min HY, El-Naggar AK, Lippman SM, Glisson B, Lee HY: Akt/mTOR counteract the antitumor activities of cixutumumab, an anti-insulin-like growth factor I receptor monoclonal antibody. Mol Cancer Ther 2011, 10:2437-2448.

61. Iravani S, Zhang HQ, Yuan ZQ, Cheng JQ, Karl RC, Jove R, Coppola D: Modification of insulin-like growth factor 1 receptor, c-Src, and Bcl-XL protein expression during the progression of Barrett's neoplasia. Hum Pathol 2003, 34:975-982.

62. LeRoith D, Baserga R, Helman L, Roberts CT Jr: Insulin-like growth factors and cancer. Ann Intern Med 1995, 122:54-59.

63. Berns EM, Klijn JG, van Staveren IL, Portengen H, Foekens JA: Sporadic amplification of the insulin-like growth factor 1 receptor gene in human breast tumors. Cancer Res 1992, 52:1036-1039.

64. De Souza AT, Hankins GR, Washington MK, Fine RL, Orton TC, Jirtle RL: Frequent loss of heterozygosity on $6 q$ at the mannose 6-phosphate/ insulin-like growth factor II receptor locus in human hepatocellular tumors. Oncogene 1995, 10:1725-1729.

65. Cui H, Cruz-Correa M, Giardiello FM, Hutcheon DF, Kafonek DR, Brandenburg S, Wu Y, He X, Powe NR, Feinberg AP: Loss of IGF2 imprinting: a potential marker of colorectal cancer risk. Science 2003, 299:1753-1755.

66. Kaneda A, Feinberg AP: Loss of imprinting of IGF2: a common epigenetic modifier of intestinal tumor risk. Cancer Res 2005, 65:11236-11240.

67. Abou-Alfa GK, Capanu M, O'Reilly EM, Ma J, Chou JF, Gansukh B, Shia J, Kalin M, Katz S, Abad L, Reidy-Lagunes DL, Kelsen DP, Chen HX, Saltz LB: A phase II study of cixutumumab (IMC-A12, NSC742460) in advanced hepatocellular carcinoma. J Hepatol 2014, 60:319-324.

68. Attias-Geva Z, Bentov I, Ludwig DL, Fishman A, Bruchim I, Werner H: Insulin-like growth factor-I receptor (IGF-IR) targeting with monoclonal antibody cixutumumab (IMC-A12) inhibits IGF-I action in endometrial cancer cells. Eur J Cancer 2011, 47:1717-1726.

69. Rowinsky EK, Youssoufian H, Tonra JR, Solomon P, Burtrum D, Ludwig DL: IMC-A12, a human IgG1 monoclonal antibody to the insulin-like growth factor I receptor. Clin Cancer Res 2007, 13:5549s-5555s

70. Chi KN, Gleave ME, Fazli L, Goldenberg SL, So A, Kollmannsberger C, Murray $\mathrm{N}$, Tinker A, Pollak M: A phase II pharmacodynamic study of preoperative figitumumab in patients with localized prostate cancer. Clin Cancer Res 2012, 18:3407-3413

71. de Bono JS, Piulats JM, Pandha HS, Petrylak DP, Saad F, Aparicio LM, Sandhu SK, Fong P, Gillessen S, Hudes GR, Wang T, Scranton J, Pollak MN: Phase II randomized study of figitumumab plus docetaxel and docetaxel alone with crossover for metastatic castration-resistant prostate cancer. Clin Cancer Res 2014, 20:1925-1934.

72. Gualberto A, Karp DD: Development of the monoclonal antibody figitumumab, targeting the insulin-like growth factor-1 receptor, for the treatment of patients with non-small-cell lung cancer. Clin Lung Cancer 2009, 10:273-280.

73. Langer CJ, Novello S, Park K, Krzakowski M, Karp DD, Mok T, Benner RJ, Scranton JR, Olszanski AJ, Jassem J: Randomized, phase III trial of first-line figitumumab in combination with paclitaxel and carboplatin versus paclitaxel and carboplatin alone in patients with advanced non-small-cell lung cancer. J Clin Oncol 2014, 32:2059-2066.

74. Schmitz S, Kaminsky-Forrett MC, Henry S, Zanetta S, Geoffrois L, Bompas E, Moxhon A, Mignion L, Guigay J, Knoops L, Hamoir M, Machiels JP: Phase II study of figitumumab in patients with recurrent and/or metastatic squamous cell carcinoma of the head and neck: clinical activity and molecular response (GORTEC 2008-02). Ann Oncol 2012, 23:2153-2161.

75. Atzori F, Tabernero J, Cervantes A, Prudkin L, Andreu J, Rodriguez-Braun E, Domingo A, Guijarro J, Gamez C, Rodon J, Di Cosimo S, Brown H, Clark J, Hardwick JS, Beckman RA, Hanley WD, Hsu K, Calvo E, Rosello S, Langdon RB, Baselga J: A phase I pharmacokinetic and pharmacodynamic study of dalotuzumab (MK-0646), an anti-insulin-like growth factor-1 receptor monoclonal antibody, in patients with advanced solid tumors. Clin Cancer Res 2011, 17:6304-6312.

76. Ellis PM, Shepherd FA, Laurie SA, Goss GD, Olivo M, Powers J, Seymour L, Bradbury PA: NCIC CTG IND.190 phase I trial of dalotuzumab (MK-0646) in combination with cisplatin and etoposide in extensive-stage small-cell lung cancer. J Thorac Oncol 2014, 9:410-413.

77. Scartozzi M, Bianconi M, Maccaroni E, Giampieri R, Berardi R, Cascinu S: Dalotuzumab, a recombinant humanized mAb targeted against IGFR1 for the treatment of cancer. Curr Opin Mol Ther 2010, 12:361-371.
78. Beltran PJ, Calzone FJ, Mitchell P, Chung YA, Cajulis E, Moody G, Belmontes B, Li CM, Vonderfecht S, Velculescu VE, Yang G, Qi J, Slamon DJ, Konecny GE: Ganitumab (AMG 479) inhibits IGF-II-dependent ovarian cancer growth and potentiates platinum-based chemotherapy. Clin Cancer Res 2014, 20:2947-2958.

79. Strosberg JR, Chan JA, Ryan DP, Meyerhardt JA, Fuchs CS, Abrams T, Regan E, Brady R, Weber J, Campos T, Kvols LK, Kulke MH: A multi-institutional, phase II open-label study of ganitumab (AMG 479) in advanced carcinoid and pancreatic neuroendocrine tumors. Endocr Relat Cancer 2013, 20:383-390.

80. Tap WD, Demetri G, Barnette P, Desai J, Kavan P, Tozer R, Benedetto PW, Friberg G, Deng H, McCaffery I, Leitch I, Badola S, Chang S, Zhu M, Tolcher A: Phase II study of ganitumab, a fully human anti-type-1 insulin-like growth factor receptor antibody, in patients with metastatic Ewing family tumors or desmoplastic small round cell tumors. J Clin Oncol 2012, 30:1849-1856

81. Van Cutsem E, Eng C, Nowara E, Swieboda-Sadlej A, Tebbutt N, Mitchell EP Davidenko I, Stephenson J, Elez ME, Prenen H, Deng H, Tang R, McCaffery I, Oliner K, Chen L, Gansert JL, Loh E, Smethurst D, Tabernero J: Randomized phase $\mathrm{lb} / \mathrm{Il}$ trial of rilotumumab or ganitumab with panitumumab versus panitumumab alone in patients with wild-type KRAS metastatic colorectal cancer. Clin Cancer Res 2014, 20:4240-4250.

82. Pappo AS, Patel SR, Crowley J, Reinke DK, Kuenkele KP, Chawla SP, Toner GC, Maki RG, Meyers PA, Chugh R, Ganjoo KN, Schuetze SM, Juergens H, Leahy MG, Geoerger B, Benjamin RS, Helman L, Baker LH: R1507, a monoclonal antibody to the insulin-like growth factor 1 receptor, in patients with recurrent or refractory Ewing sarcoma family of tumors: results of a phase II Sarcoma Alliance for Research through Collaboration study. J Clin Oncol 2011, 29:4541-4547.

83. Lin EH, Lenz HJ, Saleh MN, Mackenzie MJ, Knost JA, Pathiraja K, Langdon RB, Yao SL, Lu BD: A randomized, phase II study of the anti-insulin-like growth factor receptor type 1 (IGF-1R) monoclonal antibody robatumumab (SCH 717454) in patients with advanced colorectal cancer. Cancer Med 2014, 29:4541-4547.

84. Macaulay VM, Middleton MR, Protheroe AS, Tolcher A, Dieras V, Sessa C, Bahleda R, Blay JY, LoRusso P, Mery-Mignard D, Soria JC: Phase I study of humanized monoclonal antibody AVE1642 directed against the type 1 insulin-like growth factor receptor (IGF-1R), administered in combination with anticancer therapies to patients with advanced solid tumors. Ann Oncol 2013, 24:784-791.

85. Moreau P, Cavallo F, Leleu X, Hulin C, Amiot M, Descamps G, Facon T, Boccadoro M, Mignard D, Harousseau JL: Phase I study of the anti insulin-like growth factor 1 receptor (IGF-1R) monoclonal antibody, AVE1642, as single agent and in combination with bortezomib in patients with relapsed multiple myeloma. Leukemia 2011, 25:872-874.

86. von Mehren M, Britten CD, Pieslor P, Saville W, Vassos A, Harris S, Galluppi GR, Darif M, Wainberg ZA, Cohen RB, Leong S: A phase 1, open-label, dose-escalation study of BIIB022 (anti-IGF-1R monoclonal antibody) in subjects with relapsed or refractory solid tumors. Invest New Drugs 2014, 32:518-525.

87. Burtrum D, Zhu Z, Lu D, Anderson DM, Prewett M, Pereira DS, Bassi R, Abdullah R, Hooper AT, Koo H, Jimenez X, Johnson D, Apblett R, Kussie P, Bohlen P, Witte L, Hicklin DJ, Ludwig DL: A fully human monoclonal antibody to the insulin-like growth factor I receptor blocks liganddependent signaling and inhibits human tumor growth in vivo. Cancer Res 2003, 63:8912-8921.

88. Cohen BD, Baker DA, Soderstrom C, Tkalcevic G, Rossi AM, Miller PE, Tengowski MW, Wang F, Gualberto A, Beebe JS, Moyer JD: Combination therapy enhances the inhibition of tumor growth with the fully human anti-type 1 insulin-like growth factor receptor monoclonal antibody CP-751,871. Clin Cancer Res 2005, 11:2063-2073.

89. Nahta R, Yuan LX, Zhang B, Kobayashi R, Esteva FJ: Insulin-like growth factor-I receptor/human epidermal growth factor receptor 2 heterodimerization contributes to trastuzumab resistance of breast cancer cells. Cancer Res 2005, 65:11118-11128.

\section{doi:10.1186/s13048-014-0103-5}

Cite this article as: Wang et al:: Anti-IGF-1R monoclonal antibody inhibits the carcinogenicity activity of acquired trastuzumab-resistant SKOV3. Journal of Ovarian Research 2014 7:103. 